\title{
THE IMPORTANCE OF ORGANIZATIONAL COMMITMENT AND JOB SATISFACTION ON WORK PRODUCTIVITY AND INTENTION TO QUIT IN THE COVID 19 PANDEMIC ERA
}

\author{
Siwi Dyah Ratnasari \\ STIE Malangkucecwara, Malang, Indonesia \\ siwiratna@stie-mce.ac.id
}

\begin{abstract}
The purpose of this study was to determine the effect of: 1) Organizational commitment to intention to quit. 2) Organizational commitment to productivity. 3) Job satisfaction on productivity. 4) Job satisfaction on intention to quit. 5) Work productivity on intention to quit. This research methodology uses a quantitative approach with a survey method. Employees of PT. Johnson \& Johnson Indonesia, especially in the Medical Department, became the research population of 70 people throughout Indonesia. The number of samples was 60 people who were taken using the Slovin method. 60 questionnaires were distributed, 46 questionnaires deserved to be analyzed. Path analysis is used as a data analysis technique. The results of this study are: 1) Organizational commitment has a significant negative effect on intention to quit. 2) Organizational commitment has a significant positive effect on work productivity. 3) Job satisfaction has a significant positive effect on work productivity. 4) Job satisfaction has no effect on intention to quit. 5 . Work productivity has a significant negative effect on intention to quit. The limitation of the research is the distribution of the questionnaire using the Google form so that it is possible to miss the information obtained. Contribution: This research provides a discourse to PT Johnson \& Johnson Indonesia especially in the Medical Department that in this pandemic era employees have no intention of moving to another organization because of their high commitment even though they are actually not satisfied with the salary they receive, even though they have the opportunity.
\end{abstract}

Keywords: Organizational commitment, Job satisfaction, Intention to quit, Covid 19 Pandemic Era DOI: https://doi.org/10.24818/beman/2021.S.I.2-18

\section{INTRODUCTION}

The COVID-19 pandemic has forced many companies to adapt to change. Meanwhile, employees are also worried about whether the company where they work will be able to get through the crisis or they will lose their jobs because the company is unable to bear the burden of its employees. Anxiety over this uncertain situation affects work productivity, commitment, job satisfaction within the organization or even the employee's desire to move to another organization that is not affected by the pandemic. The implementation of PPKM as an effect of the COVID-19 Pandemic has a huge impact on employee productivity. This has a negative impact on the organization causing organizational instability. As a result, the organization carries out high turnover which results in ineffective organizational performance because 
the organization loses employees who possess experience or have special competencies and need to retrain new employees.

Intention to quit, or commonly known as turnover intention is the intention of employees to leave the company (Surbakti et al., 2021). According to the findings of Singh and Loncar (2020), to reduce the intention to quit, the employee satisfaction must be increased. Every organization wants the commitment of its employees, as it is important for the sustainability of the organization, therefore, retaining employees by keeping them motivated and committed to the organization is essential (Bhatti, 2011). A research gap is found in the research results by Damar et al. (2017): Setyadi, Suharto and Za (2020) shows that job satisfaction has a significant positive effect on intention to quit, while Nazarudin, Ma'arif, and Kuswanto (2016) found that effect of job satisfaction on intention to quit showed significant and negative results.

This study is conducted based on the inconsistency of the results of previous studies. The purpose of this research is to test and analyse the effect of: 1). Organizational commitment to intention to quit. 2). Organizational commitment to work productivity. 3). Job satisfaction on work productivity. 4). Job Satisfaction on intention to quit. 5 . Work productivity on the intention to quit.

\section{LITERATURE REVIEW AND HYPOTHESIS DEVELOPMENT}

\subsection{Organizational commitment}

Organizational commitment, according to Davis \& Newstrom (1989), is a measure of the willingness of employees to remain in a company in the future. This often reflects an employee's belief in the company's mission and goals, a willingness to put forth effort into their accomplishments, and an intention to continue working there. Employee performance is the foundation of an organization. Employees with high commitment will ensure that they will stay in the organization even though they are not satisfied (Habib et al. 2014). Various research results indicate that organizational commitment has a significant negative effect on intention to quit (Khatijah Omar et al. 2012). According to Shooshtarian, Ameli, and Aminilari (2013), commitment is the level of employee involvement, loyalty, and belief in organizational values. Employees prove loyalty when they have many job opportunities, but they prefer to stay in the organization.

\subsection{Job satisfaction}

Job satisfaction has a strong correlation with turnover, so it is important to strengthen them through implementing appropriate human resource policies (Emami et al. 2012). According to Alshitri (2013), indicators measuring job satisfaction include: 1) Salary satisfaction. Salary represents the wages earned by a person in proportion to the work done and the same as the wages received by other people in the same position. 2) The nature of the job (satisfaction with the job itself). The extent to which the job 
Ratnasari, S., D.

THE IMPORTANCE OF ORGANIZATIONAL COMMITMENT AND JOB SATISFACTION ON WORK PRODUCTIVITY

AND INTENTION TO QUIT IN THE COVID 19 PANDEMIC ERA

provides an opportunity for a person to learn, to take responsibility for certain tasks and to challenge through interesting work. According to the findings of Syamsir (2020), job satisfaction strengthens the performance of employees.

\subsection{Productivity}

Productivity measures the use of resources in an organization which is usually expressed as the ratio of the output achieved with the resources used (Armstrong, Michael, 2014). Bagus et al. (2016) state that job satisfaction among its workers is needed in order to increase their performance.

\subsection{Intention to Quit}

Intention to quit is the desire of an employee to leave the company. Intention to quit also reflects individuals who intend to leave the organization to get a better job and will end with the employee's decision to stay or leave his job. In the study by Habib et al. (2014), results show that organizational commitment has a significant effect on job satisfaction and intention to quit. According to Robbins (2003), turnover can be distinguished as: 1) Avoidable turnover (which can be avoided). This is due to better wages elsewhere, better working conditions at other companies, problems with existing leadership/administration, and the existence of other better companies. 2) Unavoidable turnover (which cannot be avoided). Employees move work to other areas due to following a spouse, changes in individual career direction, having to stay home to look after a spouse or child, and pregnancy. 3) Involuntary turnover, namely employees leave the company because they are forced to as a result of disciplinary actions taken by the company or because of lay off.

\subsection{Conceptual research}

Conceptual research is built on theory and previous empirical studies. Ekhsan, Muhamad (2019) organizational commitment negatively affects the intention to quit. In the study by Khatijah Omar et al. (2012), the results show that organizational commitment was significantly and negatively related to the intention to quit.

Then the research hypotheses are formulated as follows:

H1: Organizational commitment has a negative effect on intention to quit.

Organizational commitment and job satisfaction have an impact on employees' desire to stay in the organization (Sani and Soetjipto, 2016).

$\mathrm{H} 2$ : Organizational commitment has a positive effect on work productivity.

Productivity as the contribution to the end result of the organization total effort, in relation to the amount of resources used. Commitment and job satisfaction increase employee productivity at work (Westover et al., 2010).

H3: Job satisfaction has a positive effect on work productivity.

Foreman (2009), states that job satisfaction can reduce employees' intention to leave the company. Job satisfaction coming from employee participation can increase work productivity (Bhatti and Qureshi, 2007). Damar et al (2017); Srinadi and Suparta (2015), agree that job satisfaction has a negative and 
Ratnasari, S. D.

significant influence on the intention to quit. According to Setyadi, Suharto and Za (2020), satisfied employees provide good performance and reduce the intention to quit. Sani \& Soetjipto (2016) states that job satisfaction affects the intention to quit.

H4: Job satisfaction has a negative effect on intention to quit.

Setyadi, Suharto and Za (2020) states that employees who have high performance tend to stay inside.

H5: Work productivity has a negative effect on intention to quit.

From the hypotheses above, the research conceptual model is:

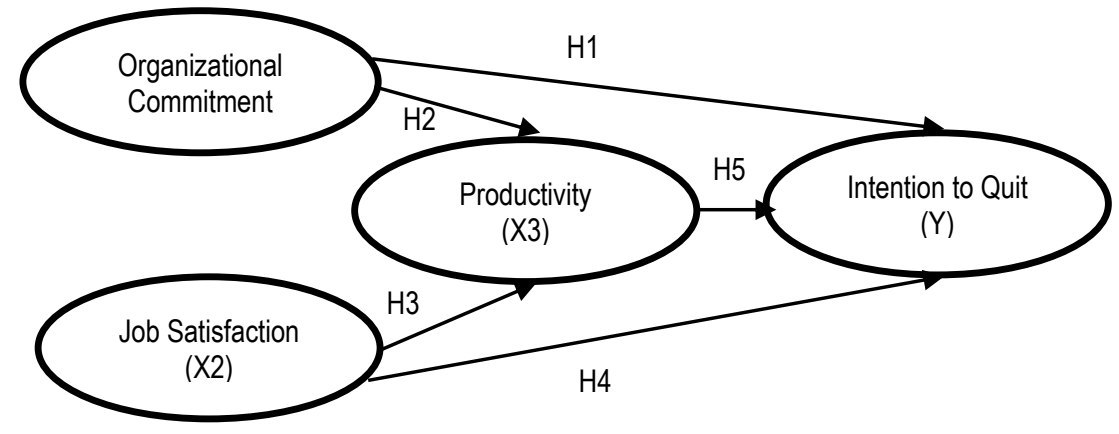

FIGURE 1. RESEARCH CONCEPTUAL MODEL

Source: The Author

\section{RESEARCH METHODOLOGY}

Quantitative approaches and survey methods are used in this study. Data were collected through a questionnaire. The research population is all employees of PT Johnson \& Johnson Indonesia Medical Division throughout Indonesia, totaling 70 people. Determination of the number of samples in this study using the Slovin formula obtained 60 respondents. Of the 60 questionnaires distributed, 46 questionnaires were deemed worthy of further analysis. The data analysis technique uses path analysis to analyze the direct and indirect effects of independent variables and dependent variables.

The research variables consist of the independent variables and the dependent variables. Independent variables consist of organizational commitment and job satisfaction. Dependent variables consist of work productivity and intention to quit. Indicators of organizational commitment consist of: 1) loyalty, and 2) belief in organizational values. (Shooshtarian, Ameli and Aminilari, 2013)

Job satisfaction as an independent variable is an individual's attitude towards his job or a series of feelings of pleasure or displeasure of an employee towards his job. There are two Job Satisfaction indicators developed in this study, consisting of: 1) Satisfaction with pay. 2) Satisfaction with job. (Luthans, Youssef, Avolio 2006)

Work productivity indicators are built from theory as Sutrisno (2009) states, namely: 1. Ability. 2. Improve the results achieved. 3. Work spirit. 4. Quality. 5. Efficiency. 
Ratnasari, S., D.

THE IMPORTANCE OF ORGANIZATIONAL COMMITMENT AND JOB SATISFACTION ON WORK PRODUCTIVITY AND INTENTION TO QUIT IN THE COVID 19 PANDEMIC ERA

Indicators of intention to quit are built on theory: Pasewark and Strawser (1996) include: 1) often think about leaving work, 2) planning to leave work next year, 3) may not have a good future if they continue to work at the company.

The measurement scale of research variables uses a Likert scale technique of 1 to 5 with the following criteria: Strongly Disagree (1), Disagree (2), Hesitate (3), Agree (4), Strongly Agree (5). (Sekaran and Bougie, 2016).

\section{RESULTS AND DISCUSSIONS}

Path analysis is used to determine the direct and indirect effects of research variables. The results of the path analysis include: 1) The Effect of Organizational Commitment (X1) and Job Satisfaction (X2) on Work Productivity (Y1), and the Effect of Organizational Commitment (X1) and Job Satisfaction (X2) on Intention to Quit (Y2).

\subsection{Direct Effect Test}

Testing the direct effect: the effect of organizational commitment (X1) on work productivity (Y1) and the effect of job satisfaction (X2) on work productivity (Y1) can be observed in table 1.

TABLE 1. THE EFFECT OF X1 AND X2 ON Y1

\begin{tabular}{|l|c|c|c|c|}
\hline \multicolumn{1}{|c|}{ Variable } & $\begin{array}{c}\text { Standardized } \\
\text { Coefficients }\end{array}$ & $\mathrm{t}_{\text {count }}$ & Sig. & Explanation \\
\hline $\begin{array}{l}\text { Organizational } \\
\text { Commitment }(\mathrm{X} 1)\end{array}$ & 0.351 & 2.342 & 0.024 & Sig \\
\hline Job Satisfaction $(\mathrm{X} 2)$ & 0.338 & 2.257 & 0.029 & Sig \\
\hline $\mathrm{R}^{2}=0,380$ & \multicolumn{2}{c}{ Sign level $5 \%$} \\
\hline
\end{tabular}

Source: Primary data processed 2021.

The $t$ test was used to determine the significant effect between the independent variable and the dependent variable partially. If $t$ count $>t$ table, or significant $t<0.05$ it means $\mathrm{Ho}$ is rejected and $\mathrm{Ha}$ is accepted.

\subsection{The Effect of Organizational Commitment (X1) on Work Productivity (Y1)}

Based on Table 1: Organizational Commitment (X1) has a t value of 2.342 at sig. t of 0.024 , which result in the decision Ho being rejected because the value of sig. $t$ is less than 0.05 . This means that the path analysis coefficient is significant. And so, Organizational Commitment (X1) has a significant positive effect on work productivity (Y1) so that the hypothesis (H2) Organizational Commitment (X1) has a significant effect on job satisfaction (Y2) is accepted.

This shows that the level of employee loyalty and belief in organizational values affects the work productivity of employees. The results of this study confirm the research of Westover et al. (2010), which concludes that commitment and job satisfaction increase employee productivity at work.

\subsection{The Effect of Job Satisfaction (X2) on Work Productivity (Y1)}

Job Satisfaction Variable (X2) has a t value of 2.257 at sig. $t$ is 0.0249 with a value of sig. $t$ less than 0.05 meaning the path analysis coefficient is significant. This means that job satisfaction (X2) has a 
significant positive effect on productivity (Y1), so the hypothesis $(\mathrm{H} 3)$ Job satisfaction $(\mathrm{X} 2)$ has a significant positive effect on work productivity (Y2) is accepted.

The results of this study confirm the research of Harter, Schmidt, and Hayes (2002), which concludes that job satisfaction can improve outcomes. Westover et al. (2010) states in addition that job satisfaction increases employee productivity at work.

Observing the analysis results in table 1, the path coefficient of organizational commitment (X1) to work productivity $(\mathrm{Y} 1)$ is 0.351 , the path coefficient of job satisfaction $(\mathrm{X} 2)$ to work productivity $(\mathrm{Y} 1)$ is 0.338 .

The coefficient of determination (contribution) of $X 1$ and $X 2$ simultaneously to $Y 1$ is 0.380 and the magnitude of the coefficient of 1 is: $1-0.380=0.620$. Table 2 reveals the Direct Effects of $X 1, X 2$ and Y1 on Y2.

TABLE 2. DIRECT EFFECTS OF X1, X2 AND Y1 ON Y2

\begin{tabular}{|l|c|c|c|c|}
\hline \multicolumn{1}{|c|}{ Variable } & $\begin{array}{c}\text { Standardized } \\
\text { Coefficients }\end{array}$ & $\mathrm{t}_{\text {count }}$ & Sig. & Explanation \\
\hline $\begin{array}{l}\text { Organizational } \\
\text { Commitment (X1) }\end{array}$ & -0.368 & -2.103 & 0.042 & Sign \\
\hline Job Satisfaction (X2) & 0.225 & 1.289 & 0.204 & Not Sign \\
\hline Productivity (Y1) & -0.354 & -2.114 & 0.041 & Sign \\
\hline $\mathrm{R}^{2}=0,269$ & \multicolumn{4}{|l}{ Sign level 5\% } \\
\hline
\end{tabular}

Source: Primary data processed 2021.

\subsection{Effect of Organizational Commitment (X1) on Intention to Quit (Y2)}

In Table 2, Organizational commitment (X1) has a t value of -2.103 at sig. $t$ of 0.042 which results in the decision Ho being rejected because the value of sig. $t$ less than 0.05 meaning the path analysis coefficient is significant. It can be concluded that organizational commitment (X1) has a significant effect on Intention to Quit ( $\mathrm{Y} 2)$, so that $(\mathrm{H} 1)$. There is a significant effect of organizational commitment $(\mathrm{x} 1)$ on intention to quit $(\mathrm{Y} 2)$ is accepted. These findings indicate that organizational commitment is the variable that has the greatest influence on Intention to Quit. This also shows that the level of employee loyalty and belief in organizational values causes employees to prefer to stay in the organization, even though there are opportunities to leave. This confirms that organizational commitment and job satisfaction have an impact on employees' desire to stay in the organization (Sani and Soetjipto 2016).

\subsection{Effect of Job Satisfaction (X2) on Intention to Quit (Y2)}

Job Satisfaction (X2) has a t-count value of 1,289 at sig. $t$ of 0.204 which results in the decision Ho being accepted because the value of sig. $t$ is greater than 0.05 meaning the path analysis coefficient is not significant. Job Satisfaction (X2) has no significant effect on Intention to Quit (Y2), so H4 There is a significant effect of Job Satisfaction (X2) on Intention to Quit (Y2) is rejected. This research reveals that employees who have been working in the organization for many years are not staying because they are satisfied with the compensation received or satisfied with their work, but for another reasons, namely 
Ratnasari, S., D.

THE IMPORTANCE OF ORGANIZATIONAL COMMITMENT AND JOB SATISFACTION ON WORK PRODUCTIVITY AND INTENTION TO QUIT IN THE COVID 19 PANDEMIC ERA

the age at which employees are no longer likely to move to another working place. The results of this study are consistent with Damar, Yasa, and Sitiari (2017); Setyadi, Suharto and Za (2020), which show that job satisfaction has a significant positive effect on intention to quit, while the results of this study do not confirm Nazarudin, Ma'arif, and Kuswanto (2016) stating that the effect of job satisfaction on Intention to Quit shows significant and negative results.

\subsection{Effect of Work Productivity (Y1) on Intention to Quit (Y2)}

The $t$ value of the Work Productivity Variable (Y1) is -2.114 at sig. $t$ of 0.041 which results in the decision Ho being rejected because the value of sig. $t$ less than 0.05 meaning the path analysis coefficient is significant. It can be concluded that Work Productivity (Y1) has a significant effect on Intention to Quit (Y2), so H5 is accepted. This shows that the ability to improve the results achieved and enthusiasm at work is able to make employees stay in the organization. The results of this study are consistent with Setyadi, Suharto and Za (2020) stating that employees who have high performance tend to stay.

\subsection{Effect of Work Productivity (Y1) on Intention to Quit (Y2)}

The $t$ value of the Work Productivity Variable (Y1) is -2.114 at sig. $t$ of 0.041 which results in the decision Ho being rejected because the value of sig. $t$ less than 0.05 meaning the path analysis coefficient is significant. It can be concluded that Work Productivity (Y1) has a significant effect on Intention to Quit (Y2), so H5 is accepted. This shows that the ability to improve the results achieved and enthusiasm at work is able to make employees stay in the organization. The results of this study are consistent with Setyadi, Suharto and Za (2020) stating that employees who have high performance tend to stay inside.

\subsection{Indirect influence test}

The indirect effect can be observed through the effect of Organizational Commitment (X1) and Job Satisfaction (X2) on Intention to Quit (Y2) through work productivity (Y1) as described in table 2 below:

TABLE 3. DIRECT EFFECT AND INDIRECT EFFECT TEST

\begin{tabular}{|c|c|c|c|c|}
\hline Variable & $\begin{array}{c}\text { Path } \\
\text { coefficient }\end{array}$ & Direct Effect & $\begin{array}{c}\text { Indirect Effect through } \\
\text { Y1 }\end{array}$ & $\begin{array}{c}\text { Total Effect } \\
\left(R^{2} \mathrm{~m}\right)\end{array}$ \\
\hline $\begin{array}{c}\text { Organizational Commitment (X1) - } \\
\text { Produktifitas kerja (Y1) }\end{array}$ & 0.351 & 0.351 & - & - \\
\hline $\begin{array}{c}\text { Organizational Commitment (X1) - } \\
\text { Intention to Quit (Y2) }\end{array}$ & -0.368 & -0.368 & $\begin{array}{c}0.351 \times-0.354=- \\
0.124\end{array}$ & - \\
\hline $\begin{array}{c}\text { Kepuasan Kerja (X2) - Produktifitas } \\
\text { kerja (Y1) }\end{array}$ & 0.338 & 0.338 & - & - \\
\hline $\begin{array}{c}\text { Kepuasan Kerja (X2) Produktifitas } \\
\text { kerja (Y1) }\end{array}$ & 0.225 & 0.225 & $0.338 \times-0.354=0.120$ & - \\
\hline $\begin{array}{c}\text { Produktifitas kerja (Y1) - Intention to } \\
\text { Quit (Y2) }\end{array}$ & -0.354 & -0.354 & - & - \\
\hline$\varepsilon_{1}$ & 0.787 & & & - \\
\hline$\varepsilon_{2}$ & 0.855 & & & 0.547 \\
\hline $\mathrm{X}_{1}, \mathrm{X}_{2}, \mathrm{Z}-\mathrm{Y}$ & & & & - \\
\hline
\end{tabular}

Source: Primary data processed 2021. 
In Table 3, Path coefficient ( $\beta Y . X 1$ ) to Intention to Quit (Y2) is -0.368 , path coefficient ( $\beta Y . X 2$ ) is Job Satisfaction (X2) to Work Productivity (Y1) is -0.225 and path coefficient ( $\beta Y . Z$ ) is Job Satisfaction to Intention to Quit (Y2) is -0.354 . The magnitude of the coefficient of determination (contribution) of $X 1$, $\mathrm{X} 2$ and $\mathrm{Y} 1$ to $\mathrm{Y} 2$ is 0.269 and the coefficient of 2 (error effect) is: $2=1-0.269=0.731=0.855$. Path coefficient ( $\beta Z . X 1)$ is Organizational Commitment $(X 1)$ to work productivity $(Y 1)$ is 0.351 , the path coefficient ( $\beta Z . X 2)$ is Job satisfaction (X2) to work productivity $(Y 1)$ is 0.3738 and the path coefficient $(\beta . Z)$ is work productivity (Y1) to Intention to Quit $(\mathrm{Y} 2)$ is -0.354 .

The magnitude of the influence of Organizational Commitment (X1) on Intention to Quit (Y2) through work productivity (Y1) is -0.124 . And so, the indirect effect of Organizational Commitment (X1) on Intention to Quit (Y2) through work productivity (Y1) is -0.124 (12.4\%). When compared with the direct effect of Organizational Commitment (X1) on Intention to Quit (Y2) of $-0.368,(36.8 \%)$, it indicates that the direct effect of Organizational Commitment (X1) on Intention to Quit (Y2) is higher than the indirect effect of Organizational Commitment (X1) on Intention to Quit (Y2) through work productivity (Y1). The results of this study are consistent with Tantowi, Said and Rahmawati (2016)'s research which concludes that work productivity $(\mathrm{Y} 1)$ as an intervening variable weakens the influence of Organizational Commitment (X1) on Intention to Quit (Y2).

The magnitude of the effect of Job Satisfaction (X2) on Intention to Quit (Y2) through Work Productivity (Y1) is - 0.120 . And so, the indirect effect of Job Satisfaction (X2) on Intention to Quit (Y2) through work productivity (Y1) is $-0.120(12.0 \%)$. These results cannot be compared with the direct effect of Job Satisfaction (X2) on Intention to Quit (Y2) because the path is not significant. From the results of the study it is also shown that work productivity (Y1) weakens the influence of Organizational Commitment (X1) on Intention to Quit (Y2), and also work productivity weakens the effect of Job Satisfaction (X2) on Intention to Quit (Y2). This reveals that employees remain in the organization because of the high commitment possessed by employees, and these results also explain that job satisfaction does not guarantee people feeling at home in the organization, but that employees are dissatisfied with the organization and remain in it because of age or other reasons that does not allow employees to transfer to other organizations.

Testing the validity of the model in the path analysis also uses the coefficient of determination.

$R 2 m=1-(0.787)$ 2. (0.855). 2

$\mathrm{R} 2 \mathrm{~m}=0.547$

This means the diversity of data that can be explained by the model is 0.547 or in other words the information contained in the data is $54.7 \%$ explained by the model, while the remaining $43.3 \%$ is explained by other variables that are not present in the model. 
Ratnasari, S., D.

THE IMPORTANCE OF ORGANIZATIONAL COMMITMENT AND JOB SATISFACTION ON WORK PRODUCTIVITY

AND INTENTION TO QUIT IN THE COVID 19 PANDEMIC ERA

\section{CONCLUSION}

From the analysis results, several conclusions are drawn: Organizational Commitment has a significant positive effect on job satisfaction, meaning that the higher the Organizational Commitment, the higher the employee productivity. The commitment of employees causes a strong desire to work. Job satisfaction has a significant positive effect on work productivity, meaning that the more satisfied employees are with their work, the more productive the employees are. Organizational Commitment has a negative effect on Intention to Quit, meaning that the higher the Organizational Commitment, the lower the Intention to Quit. Job satisfaction has no effect on Intention to Quit, meaning that changes (up and down) in Job satisfaction do not cause changes (up and down) in Intention to Quit. Work productivity has a significant negative effect on Intention to Quit, meaning that the higher the work productivity, the lower the Intention to Quit. The direct effect of Organizational Commitment on Intention to Quit is higher than the indirect effect of Organizational Commitment on Intention to Quit through work productivity. The results show that employees feel at home in the organization not because of job satisfaction, but because of their high commitment to the organization.

\subsection{Suggestion}

For organizations, building organizational commitment is much more important than other factors, because during a pandemic like this, employees even though they are not satisfied with the compensation they receive, they will persist to develop the organization. Employees who feel at home in the organization are not necessarily satisfied with the organization, but of the age factor, so it is not possible for them to work elsewhere.

\subsection{Limitation and study forward}

The limitations of the research are due to the Covid 19 pandemic, as the distribution of questionnaires has been done using Google form, so it is possible for respondents to miss the research instrument. For better results, further research can distribute questionnaires directly. Further researchers can also add other variables in the study such as external environmental conditions.

\section{REFERENCES}

Alshitri, K., I. (2013). The Effects of the Personal Variables on Organizational Commitment in Public Organizations in Saudi Arabia. IBIMA Publishing. IBIMA Business Review 2013(2013) http://www.ibimapublishing.com/journals/IBIMABR/ibimabr.html, Article ID 725189 DOI: 10.5171/2013.725189

Armstrong, M. (2014). Human Resource Management A Handbook of Human Resource Management Practice.

Bagus, I., et al. (2016). "Job Competency and Work Environment: The Effect on Job Satisfaction and Job Performance among SMEs Worker." IOSR Journal of Business and Management (IOSR- 
JBM 18(1): 19-26.

Bhatti (2011). "The Effect of Commitment and Motivation on Human Talent and Its Contribution To Organizational Performance." Management \& Marketing Challenges for the Knowledge Society 6(3): 471-82.

Bhatti, K., K., and Qureshi, T., M. (2007). Impact of Employee Participation on Job Satisfaction, Employee Commitment and Employee Productivity. International Review of Business Research Papers 3(2): 54 - 68.

Damar, A., Yasa, S., and Sitiari, W. (2017). The Influence of Work Stress and Organizational Climate on Intention to Leave with Job Satisfaction as a Mediation Variable at the Bali Provincial Industry and Trade Office." JAGADHITA: Journal of Economics \& Business 4(2): 1-13.

Davis, K., \& Newstrom, J., W. (1989). Human behavior at work: Organizational behavior. New York: McGraw-Hill.

Ekhsan, M. (2019). "The Influence Job Satisfaction and Organizational Commitment on Employee Turnover Intention." Management, and Accounting 1(October). http://e-journal.stiekusumanegara.ac.id.

Emami, R., Ebrahim, M., Durrishah, I., and Dhaifallah, O., A. (2012). "Investigating the Relationship between Organizational Learning Culture, Job Satisfaction and Turnover Intention in It SMEs." 12(April): $\quad$ 8-23. https://www.academia.edu/1538753/Investigating _the_Relationship_between_Organizational_Learning_Culture_Job_Satisfaction_and_Turnover_ Intention_in_it_SMEs.

Foreman (2009). Job satisfaction and turnover in the Chinese retail industri. Chinese Publication Study. ISSN: $1750-614 X$

Habib, Salman et al. (2014). "The Impact of Organizational Culture on Job Satisfaction, Employess Commitment and Turn over Intention." Advances in Economics and Business 2(6): 215-22.

Harter, J., K., Schmidt, F., L., and Hayes, T., L. (2002). "Business-Unit-Level Relationship between Employee Satisfaction, Employee Engagement, and Business Outcomes: A Meta-Analysis." Journal of Applied Psychology 87(2): 268-79. https://www.researchgate.net /publication/11367971_Business-Unit-

Level_Relationship_Between_Employee_Satisfaction_Employee

Engagement_and_Business_Outcomes_A_Meta-Analysis.

Khatijah, O., Marhana, M., A., Abdul, H., Abdul, M., and Husna, J. (2012). "Organizational Commitment and Intention to Leave among Nurses in Malaysian Public Hospitals." International Journal of Business and Social Science 3(16): 194-99.

Luthans, F., Youssef, C., M., \& Avolio, B., J. (2006). Psychological capital: Investing and developing positive organizational behavior. In C.L. Cooper, \& D. Nelson (Eds.), Positive organizational behavior: Accentuating the positive at work. Thousand Oaks, CA: Sage.

Nazarudin, D., Ma'arif, S., and Kuswanto, S. (2016). "Effect of Job Satisfaction and Organizational Commitment towards Employees Turnover Intention in Pasar Tohaga Bogor Company. European Journal of Business and Management 8(23): 91-100.

Pasewark, W., R., \& Strawser, J., R. (1996). The determinants and outcomes associated with job insecurity in a professional accounting environment. Behavioral Research in Accounting 8: $91-$ 113

Robbins, S., P. (2003), Organisational Behaviour, 10th ed., Prentice-Hall Inc., Upper Saddle River

Sani, A., and Soetjipto, B., E. (2016). Organizational Justice and the Role of Organizational Commitment in Mediating the Effect of Job Satisfaction on Intention to Leave (a Study at Bank 
Ratnasari, S., D.

THE IMPORTANCE OF ORGANIZATIONAL COMMITMENT AND JOB SATISFACTION ON WORK PRODUCTIVITY

AND INTENTION TO QUIT IN THE COVID 19 PANDEMIC ERA

Syariah Mandiri in Malang). International Journal of Economic Research 13(2): 587-601.

Sekaran, U., and Bougie, R. (2016) Research Methods for Business: A Skill Building Methods, Penerbit

Wiley, Amerika.

Setyadi, D., Suharto, R., B., Za, Z., S. (2020). The Important Role of Employee Satisfaction to Support Employee Performance through Quitting Intention, Productivity Management 2(32): 682-697

Shooshtarian, Z., Ameli, F., and Aminilari, M. (2013). The Effect of Labor's Emotional Intelligence on Their Job Satisfaction, Job Performance and Commitment. Iranian Journal of Management Studies 6(1): 29-45A.

http://search.proquest.com.ezproxy. saintleo.edu/docview/1400455717?accountid=4870.

Singh, P., and Loncar, N. (2020). La Satisfaction à l'Égard de La Rémunération, La Satisfaction Au Travail et l'Intention de Quitter. Relations Industrielles. 65(3): 470-90. https://doi.org/10.7202/044892ar

Srinadi, N., N., and Suparta, W., G. (2015). The Mediation Role of Job Satisfaction on the Relationship between Work Motivation and Intention to Quit. E-Journal of Economics and Business Udayana University 4.03 (2015): 197-219

Surbakti, M., N., Nasution, H., and Wibowo, R., P. (2021). Analysis of the Effect of Compensation, Job Satisfaction, Commitment and Work Environment on Turnover Intention with Job Stress as Intervening Variables on Nurses of Mitra Sejati Hospital Medan. International Journal of Research and Review 8(2): 253-63.

Sutrisno, E. (2009). Human Resource Management, 1st. Kencana Prenada Media Group, Jakarta

Syamsir, S. (2020). Competence, Job Satisfaction, Work Motivation, and Job Performance of The Village ('Nagari') Masters in Managing E-Village Finance. International Journal of Advanced Science and ... 29(08): 1337-50. http://repository.unp.ac.id/26930/.

Tantowi, A., Said, L., R., and Rahmawati, R. (2016). The Effect of Financial and Non-Financial Compensation on Job Satisfaction and Its Impact on Turnover Intention on Seafarers at PT. Maritime Barito Perkasa Banjarmasin. JWM (Journal of Management Insights) 4(1):11-21

Westover, J., H., Westover, A., R., and Westover, L., A. (2010). Enhancing Long-Term Worker Productivity and Performance: The Connection of Key Work Domains to Job Satisfaction and Organizational Commitment. International Journal of Productivity and Performance Management 59(4): 372-87. 